\title{
Rudolf Ludwig Karl Virchow: pathologist, physician, anthropologist, and politician
}

\author{
Implications of his work for the understanding of cerebrovascular \\ pathology and stroke
}

\author{
Sam Safavi-Abbasi, M.D., Ph.D., Cassius Reis, M.D., Melanie C. Talley, Ph.D., \\ Nicholas Theodore, M.D., Peter Nakaji, M.D., Robert F. SPetzler, M.D., \\ and Mark C. Preul, M.D.
}

\begin{abstract}
Neurosurgery Research Laboratory, Division of Neurological Surgery, Barrow Neurological Institute, St. Joseph's Hospital and Medical Center, Phoenix, Arizona; and Department of Neurosurgery, International Neuroscience Institute of Hannover, Germany
\end{abstract}

\begin{abstract}
$\mathrm{U}$ The history of apoplexy and descriptions of stroke symptoms date back to ancient times. It was not until the midnineteenth century, however, that the contributions of Rudolf Ludwig Karl Virchow, including his descriptions of the phenomena he called "embolism" and "thrombosis" as well as the origins of ischemia, changed the understanding of stroke. He suggested three main factors that conduce to venous thrombosis, which are now known as the Virchow triad. He also showed that portions of what he called a "thrombus" could detach and form an "embolus." Thus, Virchow coined these terms to describe the pathogenesis of the disorder. It was also not until 1863 that Virchow recognized and differentiated almost all of the common types of intracranial malformations: telangiectatic venous malformations, arterial malformations, arteriovenous malformations, cystic angiomas (possibly what are now called hemangioblastomas), and transitional types of these lesions. This article is a review of the contributions of Rudolf Virchow to the current understanding of cerebrovascular pathology, and a summary of the life of this extraordinary personality in his many roles as physician, pathologist, anthropologist, ethnologist, and politician.
\end{abstract}

\section{Key Words • Rudolf Ludwig Karl Virchow • apoplexy • stroke • cerebrovascular disease • history of neurosurgery}

\footnotetext{
"In science the credit goes to the man who convinces the world, not the man to whom the idea first occurs."
}

- Sir Francis Darwin

(1848-1925 [Charles Darwin's son])

In the Oxford English Dictionary the first synonym for the term "stroke of the palsy" is recorded as a "stroke of God's hands." Hippocrates (460-370 B.C.) described paralysis of the right arm with loss of speech in what is probably the first written description of aphasia. In one of his aphorisms he stated, "Unaccustomed attacks of numbness and anesthesia are signs of impending apoplexy." "Apoplexy," from the Greek word meaning "struck with violence as if by a thunderbolt," first appeared in the Hippocratic writings. "Stroke," the modern description for apoplexy, is thus related to the ancient Greek term. Today, use of the word "stroke" has almost displaced the archaicsounding "apoplexy." Unlike the German Schlag and French coup, the word "stroke" acquires its connotation simply from its context and requires no further explanation. ${ }^{8}$

"Carotid," also of Greek derivation, from the term $\mathrm{ka}$ rotide or karos, means to plunge into deep sleep or to stupefy. When this term was coined, it reflected an understanding of the role of the neck vessels in neurological function. ${ }^{4}$ Galen (A.D. 131-201) was aware that hemiplegia resulted from a lesion in the opposite side of the brain, but he attributed hemorrhage to an accumulation of phlegm in the cerebral arteries. ${ }^{5,6}$ The Persian medieval physician Ibn Sina, known in the West as Avicenna (A.D. 980-1037), described in his influential Canon of Medicine, among many other neurological symptoms, apoplexy, paralysis, and epilepsy. ${ }^{3}$ As $\mathrm{Has}^{2}$ relates, Avicenna defined apoplexy as "loss of sensibility and movement following an occlusion seated within the brain in those places traversed by the nervous influx of sensibility and motoricity."

The historical accounts of apoplexy date back to the ancient Egyptians, and hemiparesis is described in the Edwin Smith Papyrus. ${ }^{3}$ Besides the aforementioned authors, many others have contributed to the history and understanding of this entity; their names and individual biographies are beyond the scope of this article. However, not until the mid-nineteenth century did Rudolf Virchow's descriptions of embolism, thrombosis, and the causes of ischemia change the understanding of apoplexy and lead to our modern understanding of stroke. In this article we review his contributions to the understanding of cerebrovascular pathology and his life as physician, pathologist, anthropologist, ethnologist, and politician.

\section{Early Life}

Rudolf Ludwig Karl Virchow (Fig. 1) is considered the most prominent German physician of the nineteenth centu- 


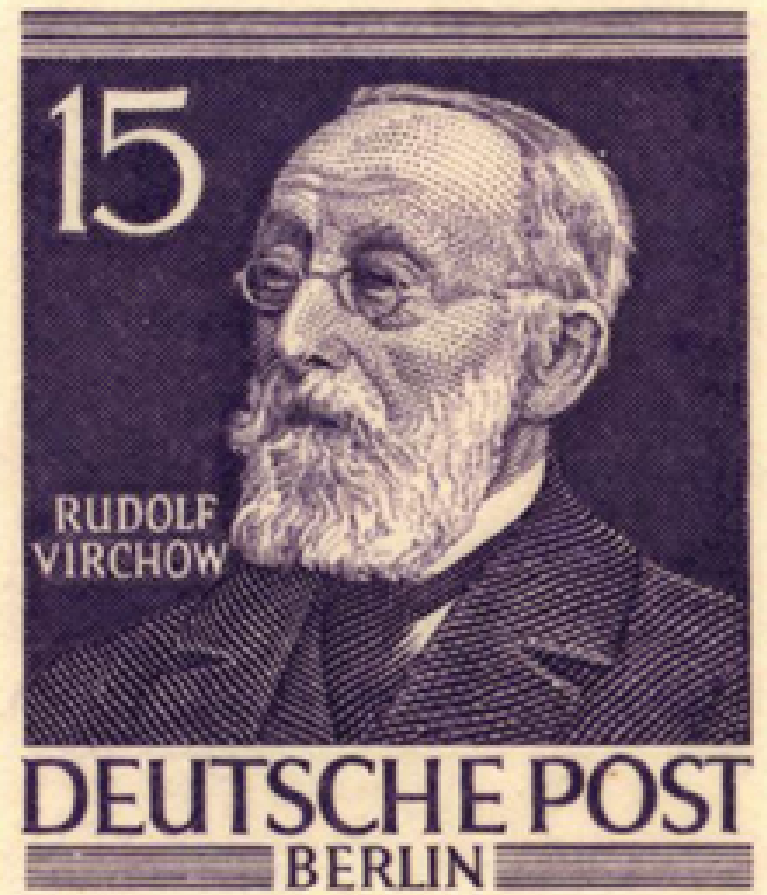

FIG. 1. Rudolf Ludwig Karl Virchow (1821-1902) portrayed on a German stamp. (Adapted from: http: //library.utmem.edu/ HSLBC/history/stamps/StampsLarge/VirchowGermany.gif.)

ry. ${ }^{4,5} \mathrm{He}$ was born on October 13,1821 , in Schievelbein, eastern Pomerania (today Poland) as the only son of a merchant. In 1839 he received a military fellowship to study medicine in Berlin at the Friedrich-Wilhelms-Institut, the military academy of Prussia. He worked there under an inspiring teacher, Johannes Peter Mueller (1801-1858, Fig. 2).

Mueller, who was a professor of physiology and anatomy and a gifted neurophysiological researcher, conducted electrophysiological experiments that confirmed that the dorsal roots of the spinal cord carried information about sensation and that the anterior roots controlled movement. ${ }^{5}$ These findings led to the development of his law of specific nerve energies: he maintained that each sensory nerve, however stimulated, only gives rise to a single specific sensation. The optic nerve, for example, only produces the sensation of light regardless of whether stimulated by mechanical, electrical, or thermal energy. Thus, Mueller conceived that the human mind did not perceive the processes of the external world per se, but rather the alterations produced by the afferent and efferent systems. Mueller's Handbuch der Physiologie (Handbook of Physiology) became the physiologist's bible. In 1843 Virchow defended his doctoral dissertation on the corneal manifestations of rheumatic disease (De rheumate praesertim corneae). To his parents he would later write that he received his degree from the "world's most famous physiologist (Johannes Mueller)." ${ }^{4}$

In the autumn of 1844 , Virchow received an appointment as "company surgeon" at the Charité Hospital in Berlin, where he rotated through various services. Virchow, an articulate spokesman for the new generation of

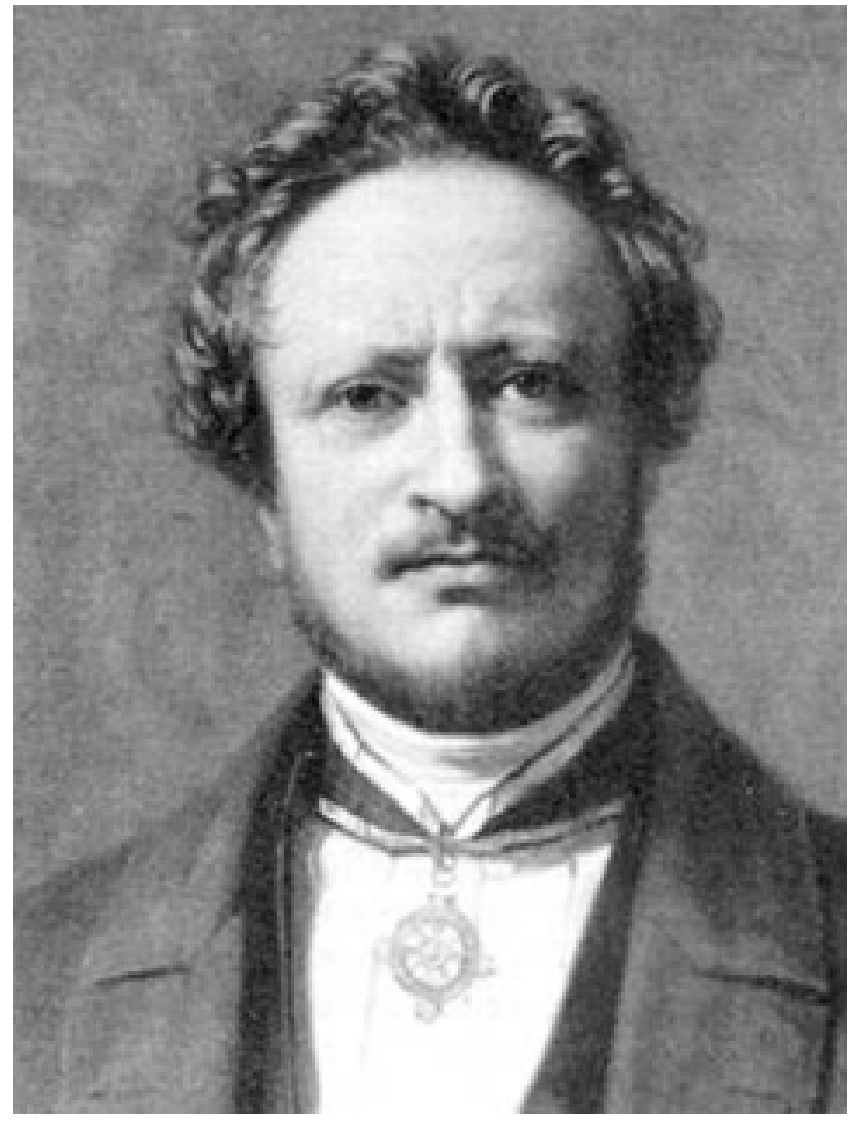

FIG. 2. Portrait of Virchow's mentor, Johannes Peter Mueller (1801-1858). (Adapted from: http://upload.wikimedia.org/wiki pedia/en/9/99/Mueller.Joh..jpg.)

physicians at his time, envisioned medical progress from three main sources: clinical observations, animal experiments to search for causes of disease and to evaluate drug effects, and pathological anatomy, especially at the microscopic level.

Although he was confident in his beliefs, his provocative ideas generated hostility among his older peers. Nonetheless, he passed his licensing examination in $1846 .{ }^{4}$ Dissatisfied with the editors of various journals that refused to publish two of his manuscripts, in 1846 Virchow, together with the prominent pathologist Benno Ernst Heinrich Reinhardt (1819-1852), founded a new journal: Archiv für pathologische Anatomie und Physiologie und für klinische Medizin (Archives of Pathological Anatomy and Physiology and of Clinical Medicine). This journal became one of the most prominent medical periodicals of the time. After Reinhardt's death in 1852, Virchow continued as sole editor of the journal until his death 50 years later. The publication was eventually renamed Virchow's Archiv. ${ }^{4,5,8} \mathrm{Au}-$ thors who submitted manuscripts with outdated, untested, or speculative and dogmatic ideas feared his sharp tongue and critical writing.

\section{The Revolutionist}

In 1848 the Prussian government commissioned Virchow, then 27 years old, to investigate an epidemic of typhus in 
famine-ridden Upper Silesia (Oberschlesien). For 3 weeks Virchow worked among the impoverished Polish minority there who were struggling for survival. The impact of this encounter reinforced his already liberal social and political beliefs. From Virchow's point of view the epidemic was largely due to the bad living conditions. Instead of returning with a proposal for humanitarian, hygienic, and medical guidelines as expected by the government, Virchow recommended political freedom as well as social and educational reforms for the people of Upper Silesia (Mitteilungen ueber die in Oberschlesien herrschende TyphusEpidemie, Berlin 1849). ${ }^{13}$ This compassionate plea made him very unpopular with the government.

Just 8 days after his return from Silesia, he helped to construct some barricades in Berlin during the 1848 liberal revolution in that city, and participated in a movement of doctors to appoint a minister of health. Suspended from his position at the Charité and forced from Berlin after his courageous support for the uprising, he moved to Würzburg. There, making the best of internal exile, he devoted himself to the study of cells for 7 years..$^{5,8}$ Nevertheless, Virchow remained an active political agitator for liberal reforms throughout his life. From 1848 to 1849 he published a weekly newspaper, Die Medizinische Reform (The Medical Reformation), much of which he wrote himself. Virchow is credited with the founding of "European social medicine," which frequently focuses on the fact that disease often has associations with social conditions (as in Upper Silesia). Virchow believed that the "physician was the natural advocate for the poor." 4,5

During his 7 years in Würzburg he accomplished some of his most prominent scientific achievements and became internationally famous. Many of his pupils also attained medical fame; this group included Edwin Klebs (18341913), who described the diphtheria bacillus, also known as "Klebs-Löffler bacillus"; Ernst Haeckel (1834-1919), who proposed that "ontogeny recapitulates phylogeny"; and Adolf Kussmaul (1822-1902), who was the first to describe polyarteritis nodosa, mesenteric embolism, and a characteristic pathological pattern of breathing ("Kussmaul" respiration). ${ }^{4}$

In Würzburg, Virchow started the publication of his monumental, six-volume textbook Handbuch der speziellen Pathologie und Therapie (Handbook of Special Pathology and Therapeutics). ${ }^{1,5,8} \mathrm{He}$ also simultaneously began his anthropological work and his investigations into the embryological development of the base of the skull. He formulated his findings on cellular pathology and emphasized that diseases arose, not in organs or tissues in general, but primarily in their individual cells. Virchow pioneered the modern concept of pathological processes by his application of "cell theory" to explain the effects of disease in the organism.

\section{Contradictory Theories}

Another of Mueller's pupils, Theodor Schwann (18101882), who is famous for discovering the enzyme pepsin, argued that in embryological development and in certain pathological situations, such as inflammation, new cells formed from blastema. Similar possibilities were proposed by Karl Rokitansky (1804-1878, Fig. 3), a profes-

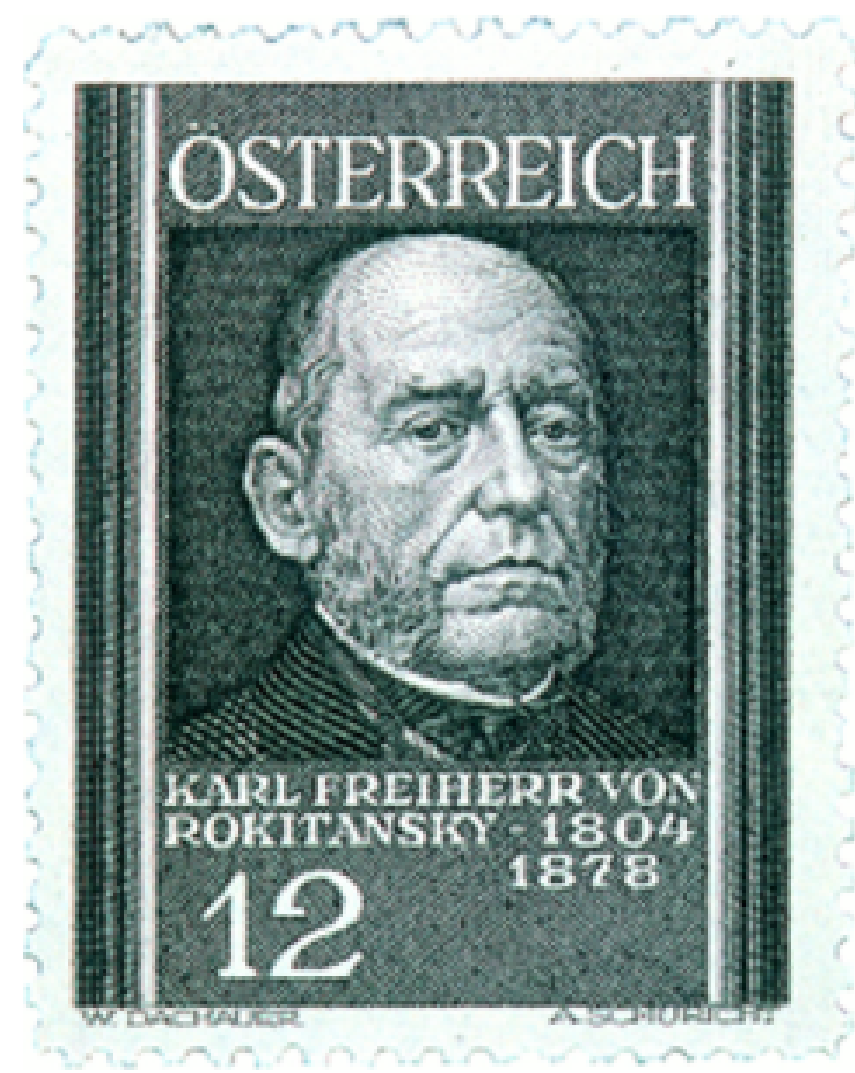

FIG. 3. Portrait of Karl Rokitansky (1804-1878) shown on an Austrian stamp. (Adapted from: http://www.stamps.journalclub. org/stampgifs/13.jpg.)

sor of pathology and anatomy in Vienna who allegedly performed more than 60,000 autopsies throughout his career. ${ }^{5}$ During autopsies Rokitansky often found no gross pathological changes sufficient to explain the cause of death. He therefore speculated that conditions affecting the blood sometimes caused the blastema to spawn abnormal cells, leading to disease. He developed a theory of neohumoralism, which held that diseases originated in an imbalance of protein substances such as fibrin and albumin. Rokitansky included these hemato-humoral concepts of pathogenesis in his Handbuch der pathologischen Anatomie (Handbook of Pathological Anatomy).

Together with Robert Remak (1815-1865), a practicing Jew, Virchow distrusted all such concepts, maintaining that cells always arose from preexisting cells. Although he made distinguished contributions in many fields, notably neurology, Remak was denied his due rewards and never gained a professor's chair in Germany because of antisemitism. ${ }^{5}$ Virchow soon abandoned the blastema theory altogether, stating that "there is no life but through direct succession;" thus, every cell is derived from a preexisting one (Omnis cellula e cellula). He gave a celebrated series of 20 lectures in Berlin, published as Die Cellularpathologie (Cellular Pathology) in $1858 .{ }^{10}$ Herein, he reiterated his thesis that diseases came from abnormal changes within cells. 


\section{Contributions to the Understanding of Cerebrovascular Pathology}

The finding of what we call arteriosclerosis indeed precedes the nineteenth century and Virchow. Descriptions of the symptoms of stroke date back to ancient times. Gregor Nymann of Wittenberg recognized that an apoplectic attack could result from closure of the vessel that bore the vital spirits to the brain. ${ }^{6}$ In 1677 Francois Bayle (1622-1709) described arteriosclerosis in cerebral arteries and related the findings to apoplexy. Hermann Boerhaave (1668-1738) and Thomas Willis (1621-1675) spoke about "cartilaginous" change in the carotid artery (stenochoria in chondrogonia arteriae). ${ }^{8}$ The term "arteriosclerosis" was first used in 1829 by a German-born French pathologist, Jean Georges Chrétien Fréderic Martin Lobstein (1777-1835). Lobstein described the arterial thickening and a "yellow puree-like" appearance but could not explain its cause. Virchow later revived the term and contributed to the understanding of the disease origins.

Virchow's "epoch-making" paper on embolism was published in 1847.14 By 1848 he had demonstrated that masses in the blood vessels resulted from "thrombosis" (his term). ${ }^{4,12} \mathrm{He}$ suggested three main predisposing factors to venous thrombosis, which are now known as the Virchow triad (irregularity of the lumen, impaired blood flow, and increased coagulability). ${ }^{12} \mathrm{He}$ showed that portions of a thrombus could detach and form an "embolus" (also his term). Since antiquity a thrombus has been variously called a coagulum, clot, or curd in blood and milk. Long before Virchow, the term "embolus" had a variety of connotations; however, they were different from his and ours today. Jean Cruveilhier (1791-1874), who dominated the field of pathology in the 1840s when Virchow entered it, wrote about the understanding of emboli or blood clotting: "a doctrine which had been around for a long time, in practice rather than in science. But it has taken a new turn since the important work by Virchow who has recently given the name emboli to these clots."

At that time, Rokitansky ${ }^{7}$ published a four-volume manual on pathological anatomy. He insisted on a novel concept to explain hemorrhagic apoplexy. Presumably, he had performed more autopsies than anyone before him and had observed that many apoplexies were associated with congestion or dilation of the right ventricle and heart disease. He therefore assumed that hemorrhage was due to hypertrophy of the left ventricle and hence to an increased "impulse." The concept of high blood pressure was not being taken seriously at that time. Brittle arteries alone or in combination with the aforementioned factors were contributory. Rokitansky recognized that an "anomalous condition of blood" and "so-called ossification" of the arteries and atrophy of the brain were associated with the disease. He also recognized that the associated encephalomalacia was "quite problematical" and assumed an underlying "chemico-pathological process." Rokitansky, however, could see no cause and could make no contribution to the understanding of the pathogenesis of stroke and encephalomalacia. As recounted by Schiller, ${ }^{8}$ he expressed regret for having no more information to give.

Rokitansky was approximately 40 years old when his work appeared. In 1847, 3 years thereafter, Virchow was only 26 years old. This was the year before he was forced to leave Berlin for his liberal activities on the barricades. ${ }^{8}$ At this time, as mentioned earlier, he published the first volume of the Archiv für pathologische Anatomie und Physiologie und für klinische Medizin, which was later renamed Virchow's Archiv. ${ }^{12,14} \mathrm{He}$ had cofounded this journal when two of his papers directed against the inflammatory theory of thrombosis had been rejected.

As Schiller ${ }^{8}$ details, Virchow ridiculed the confusion surrounding the origin of thrombosis: "where the results of observation are buried under such a gaudy mixture of seemingly empirical views, a priori speculations, and clinical arbitrariness." Here, the different philosophies and approaches to the understanding of the pathogenesis of disease clashed. Rokitansky's medical philosophy, as outlined in Porter, ${ }^{5}$ was that "pathological anatomy must constitute the groundwork, not only of all medical knowledge, but also of all medical treatment." In contrast, as Mueller's protégé, Virchow, because he had been trained in physiology, microscopy, and animal experimentation, advocated more than pure clinical observations and study of pathological anatomy. Virchow stated that "in thrombosis inflammation is a secondary event due to a chemical alteration of the thrombus... it has been shown experimentally by [Francois] Magendie [1783-1855] and [Robert] Carswell [1793-1857], with strings placed into the lumen of vessels" as he had discussed in his two rejected papers. He further concluded, "I feel perfectly justified in claiming that these clots never originated in the local circulation but that they are torn off at a distance and carried along in the blood stream as far as they can go." "12,14

Virchow was the first to recognize cerebral and lung embolism. ${ }^{2,4}$ In 1856, investigating cerebrovascular ischemia, he described carotid thrombosis associated with ipsilateral blindness and found the lumens of the ophthalmic and central retinal arteries to be patent. ${ }^{9}$ Virchow's work on problems of vascular pathology was "continued, crowned, and superseded" by his extraordinary student, Julius Cohnheim. Cohnheim injected wax globules into arteries to lodge as emboli in the tongues of frogs. ${ }^{8}$ Cohnheim realized that such embolization produced two kinds of lesions: what he called "ischemic necrosis" in contrast with "hemorrhagic infarct." Thus, Cohnheim used the term "infarct" to cover "ischemic necrosis," as the term is used today. Cohnheim dedicated his work on embolism to his mentor Rudolf Virchow.

Virchow's role in the understanding of cerebrovascular pathology encompassed more than the understanding of stroke. In 1863, in his monumental three-volume treatise on blood vessels, Virchow also recognized and differentiated almost all of the common types of intracranial malformations: telangiectatic venous malformations, arterial malformations, arteriovenous malformations, and cystic angiomas (possibly what are now called hemangioblastomas). Moreover, Virchow also recognized transitional types of these lesions., ${ }^{311}$

\section{Second Period in Berlin}

In 1856 Virchow returned to Berlin to become director of the Pathological Institute, where he trained a new generation of pathologists. His institute became a famous center for many scientists. Virchow trained such notables as Ernst Felix Immanuel Hoppe-Seyler (1825-1895), who 


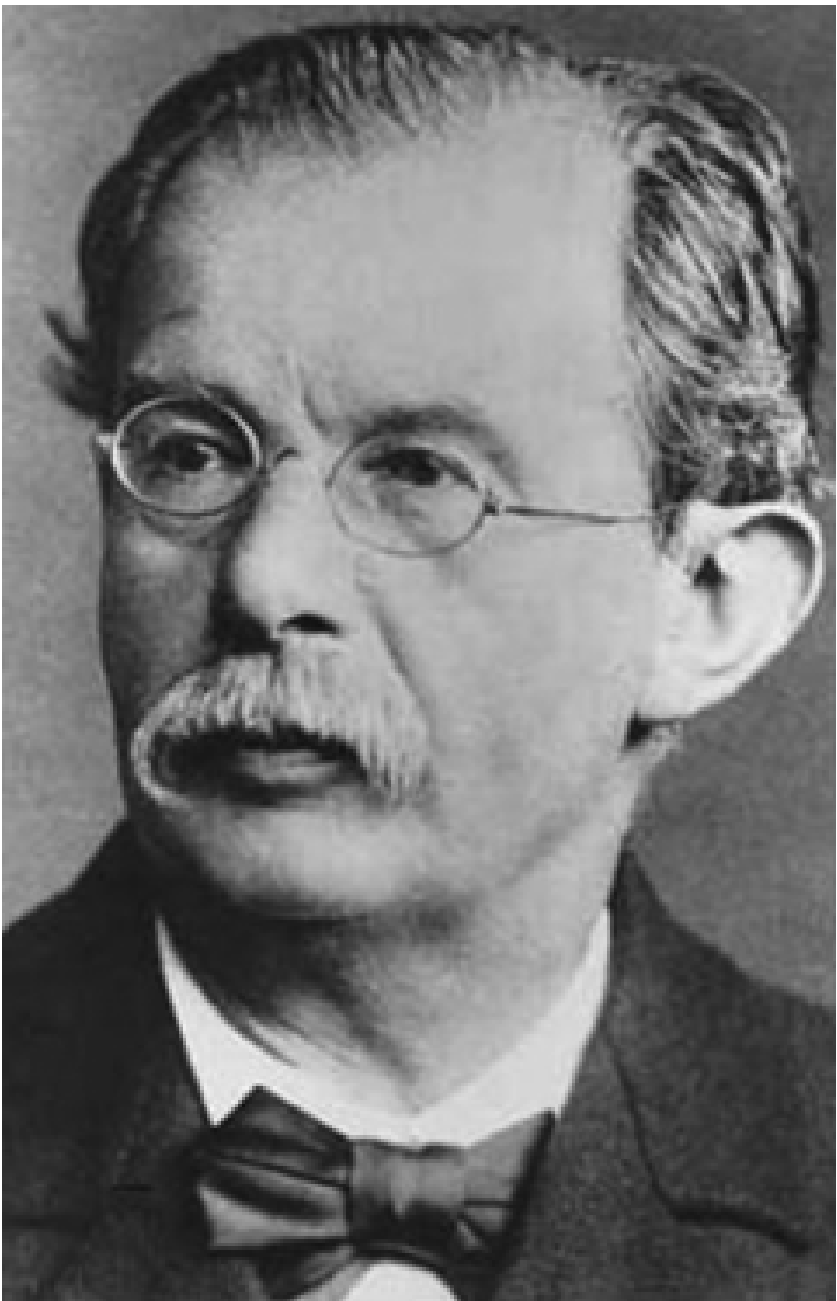

FIG. 4. Portrait of Virchow's pupil, Friedrich Daniel von Recklinghausen (1833-1910). (Adapted from: http://www. uni-wuerzburg.de/pathologie/Virchow/bilder/66.jpg.)

investigated the chemical and optical characteristics of hemoglobin; Friedrich Daniel von Recklinghausen (18331910), who described neurofibromatosis, also known as von Recklinghausen disease (Fig. 4); and Julius Friedrich Cohnheim (1839-1884), who continued Virchow's work on thrombosis and embolism and described leukodiapedesis (Fig. 5). Virchow remained in charge of the clinical section of the Charité hospital for almost 20 years.

During this second period in Berlin, Virchow again became actively engaged in politics. In 1859 he was elected to the Berlin City Council. For the rest of his life he focused on public health matters, such as sewage disposal, meat inspection (he had discovered trichinosis), schools, and public hygiene. ${ }^{4,15}$ With friends he founded the new liberal Deutsche Fortschrittspartei (German Progressive Party). In the German Reichstag (Parliament) from 1880 to 1893, Virchow was a forceful opponent of the conservative, aristocratic monarchist Otto von Bismarck, the "Iron Chancellor." In 1865, Bismarck, having had open disagreements over politics and having become annoyed with "der kleine Doktor" ("the little doctor"), challenged him to a duel, which Virchow wisely declined.

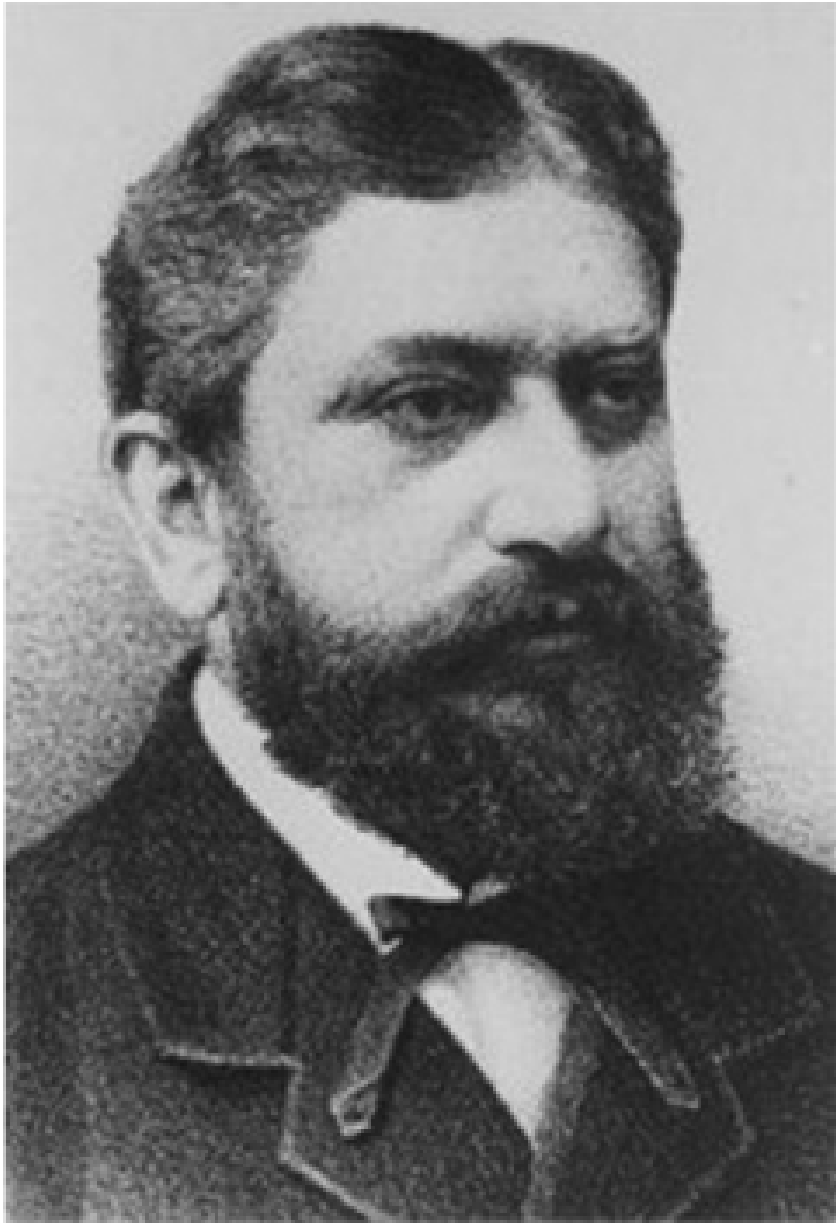

FIG. 5. Portrait of Virchow's pupil, Julius Friedrich Cohnheim (1839-1884). (Adapted from: http://www.uni-leipzig.de/ psy/ cohn.html.)

A champion of public hygiene and social reform, Virchow conducted a study of the physiques of more than 6 million German children, concluding that fitness was a product of living conditions and not race. Criticizing the emerging Teutonic racial theories of the conservative and aristocratic parties, Virchow denied the existence of a pure Aryan race. $^{4,5}$

\section{Later Life and Other Contributions}

Virchow was fascinated by anthropology and in 1879 accompanied Heinrich Schliemann (1822-1890) to excavate Troy. ${ }^{4,5}$ At that time, great interest had developed in Charles Darwin's (1809-1882) theories. Although Virchow recognized their merit, he warned against the exaggerated, enthusiastic claims of some evolutionary theorists. In 1881 and in 1894, pursuing his interest in archeology and anthropology, he made expeditions to the Caucasus. He was cofounder of the German Anthropological Society in 1869. In the same year he also cofounded the Society for Anthropology, Ethnology, and Prehistory (Deutsche Gesellschaft für Anthropologie, Ethnologie und Urgeschichte), of which he remained president until his death.

Virchow continued to lecture, write, edit, research, serve in political bodies, and to influence international medicine 
until his death. Ever fearless and highly active at the age of 81 years, he jumped prematurely from a moving passenger tram in Berlin, fractured his hip, and died soon thereafter. On September 5, 1902, this remarkable personality was honored with a state funeral in Berlin. ${ }^{4,5}$

Rudolf Virchow contributed much more than the cell theory. Among many other findings, he described the perivascular spaces of the nervous system (Virchow-Robin space). He recognized the phagocytic nature of neuroglia in encephalomalacia, ${ }^{17}$ the blood-borne pathogenesis of syphilis, ${ }^{16}$ and contributed to the understanding of pulmonary aspergillosis. ${ }^{12} \mathrm{He}$ wrote about tumors of the spinal cord, ${ }^{11}$ provided one of the earliest descriptions of platybasia, discovered the substance he called "amyloid," and first described leukemia. ${ }^{1,12,18}$

\section{Conclusions}

This extraordinary personality, whose formidable productivity testifies to his immense energy, had a central role in the understanding of cerebrovascular pathology and stroke. An exhaustive list of his publications and biographies can be found in Ole Daniel Enersen (http:// www.whonamedit.com/doctor.cfm/912.html).

\section{Acknowledgments}

We express our appreciation to Ms. Judy Wilson and the Neuroscience Publications Office of Barrow Neurological Institute for their help in the preparation of this manuscript.

\section{References}

1. Haas LF: Rudolph Ludwig Carl Virchow (1821-1902). J Neurol Neurosurg Psychiatry 61:578, 1996

2. Has LF: Avicenna or Ibn Sina (980-1036 AD). J Neurol Neurosurg Psychiatry 54:682, 1991

3. Heros RC, Morcos JJ: Cerebrovascular surgery: past, present, and future. Neurosurgery 47:1007-1033, 2000

4. Pearce JMS: Rudolf Ludwig Karl Virchow (1821-1902). J Neurol 249:492-493, 2002
5. Porter R: The Greatest Benefits to Mankind: A Medical History of Humanity. New York: Norton \& Company, 1997

6. Quest DO: Stroke: a selective history. Neurosurgery 27: 440-445, 1990

7. Rokitansky K: A Manual of Pathological Anatomy. London: Sydenham Society, 1856

8. Schiller F: Concepts of stroke before and after Virchow. Med Hist 14:115-131, 1970

9. Thompson JE: The evolution of surgery for the treatment and prevention of stroke. The Willis Lecture. Stroke 27: 1427-1434, 1996

10. Virchow RLK: Die Cellularpathologie in ihrer Begründung auf physiologische und pathologische Gewebenlehre. Berlin: Hirschwald, 1858

11. Virchow RLK: Die Krankhaften Geschwülste. Berlin: Hirschwald, 1863

12. Virchow RLK: Gesammelte Abhandlungen zur Wissenschaftlichen Medizin. Frankfurt: Meidinger Sohn \& Co, 1856

13. Virchow RLK: Mitteilungen ueber die in Oberschlesien herrschende Typhus-Epidemie, ed 2. Arch für path Anat u Physiol und für klin Med 2:143-322, 1849

14. Virchow RLK: Ueber die akute Entzuendung der Arterien. Arch für Path Anat u Physiol und fur klin Med Berlin 1: 272-274, 1847

15. Virchow RLK: Ueber die Kanalisation von Berlin. Zschr Gerichtl Off Med 9:1-43, 1868

16. Virchow RLK: Ueber die Natur der konstitionell-syphilitischen Affectionen. Arch für Path Anat u Physiol und für klin Med Berlin 15:217-336, 1858

17. Virchow RLK: Ueber eine im Gehirn und Rückenmark des Menschen aufgefundene Substanz mit der chemischen Reaktion der Cellulose. Arch für path Anat u Physiol und für klin Med Berlin 6:135-138, 1854

18. Virchow RLK: Weisses Blut. Neue Notizen. Natur u Heilk Weimar 36:151-156, 1845

Manuscript received March 24, 2006.

Accepted in final form May 11, 2006.

Address reprint requests to: Mark C. Preul, M.D, c/o Neuroscience Publications, Barrow Neurological Institute, 350 West Thomas Road, Phoenix, Arizona 85013. email: neuropub@chw.edu. 